\title{
Preparation and Characterization of NiZn-Ferrite Nanofibers Fabricated by Electrospinning Process
}

\author{
Yong-Hui Joo*,**, Joong-Hee Nam**, Jeong-Ho Cho*, Myoung-Pyo Chun*, Byung-Ik Kim*, and Tae-Gyung Ko ${ }^{* *}$ \\ *Advanced Materials \& Components Laboratory, Korea Institute of Ceramic Engineering and Technology, Seoul 153-801, Korea \\ **School of Materials Science and Engineering, Inha University, Inchon 402-751, Korea \\ (Received November 11, 2008; Revised December 15, 2008; Accepted December 22, 2008)
}

\section{전기방사법에 의한 NiZn 폐라이트 나노섬유의 제조 및 특성 연구 \\ 주용휘*** • 남중희*† · 조정호* · 전명표* · 김병익* · 고태경** \\ *요업기술원 첨단소재·부품빔 \\ **인하대학교 신소재공학부 \\ (2008년 11월 11일 접수; 2008년 12월 15일 수정; 2008년 12월 22일 승인)}

\begin{abstract}
Electrospinning process is the useful and unique method to produce nanofibers from metal precursor and polymer solution by controlled viscosity. In this study, the NiZn ferrite nanofibers were prepared by electrospinning with a aqueous metal salts/polymer solution that contained polyvinyl pyrrolidone and $\mathrm{Fe}$ (III) chloride, $\mathrm{Ni}$ (II) acetate tetrahydrate and zinc acetate dihydrate in N,Ndimethylformamide. The applied electric field and spurting rate for spinning conditions were $10 \mathrm{kV}, 2 \mathrm{~m} l / \mathrm{h}$, respectively. The obtained fibers were treated at $250^{\circ} \mathrm{C}$ for $1 \mathrm{~h}$ to remove the polymer. Finally, the NiZn ferrite fibers were calcined at $600^{\circ} \mathrm{C}$ for $3 \mathrm{~h}$ and annealed at $900 \sim 1200^{\circ} \mathrm{C}$ in air. By tuning the viscosity of batch solution before electrospinning, we were able to control the microstructure of $\mathrm{NiZn}$ ferrite fiber in the range of $150 \sim 500 \mathrm{~nm}$ at $770 \mathrm{cP}$. The primary particle size in $600^{\circ} \mathrm{C}$ calcined ferrite fiber was about $10 \mathrm{~nm}$. The properties of those $\mathrm{NiZn}$ ferrite fibers were determined from X-ray diffraction analysis, electron microscopy, energy dispersive spectroscopy, Fourier transform infrared spectroscopy, thermal analysis, and magnetic measurement.
\end{abstract}

Key words : Electrospinning, Ferrite nanofiber, NiZn ferrites, Multiple grain

\section{1. 서 론}

1차원구조(One-dimensional structure)의 나노재료는 벌크 재료와는 다른 독특한 성질을 가지고 있어 학문적으로나 실용적으로 많은 관심을 끌고 있다 ${ }^{1\}}$. 최근, 이러한 나노 재로의 제조법, 분석법 그리고 상업적으로 적용하기 위한 연구가 학계와 산업 전반적으로 이루어지고 있다. ${ }^{2)}$ 현재 까지 다양한 형상을 갖는 나노재로를 제조할 수 있는 많 은 방법들이 제시되었으며, 그 중에서 전기방사법은 나노 섬유를 제조함에 있어서 가장 손쉬운 방법으로 손끕히고 있다.

전기방사의 원리를 간단히 설명하면 다음과 같다. 바늘 끝에 매달려 있는 용액에 고전압을 가하게 되면 전하의 집 적이 발생하게 되고, 그로 인해 taylor cone이 형성된다. 이 때, 임계전압을 넘어서게 되면 cone-jet이 발생한다. ${ }^{3)}$ 용

Corresponding author: Joong-Hee Nam

E-mail : jnam@kicet.re.kr

Tel : +82-2-3282-2443 Fax : +82-2-3282-7759
액의 점성을 조절함에 따라 미세한 입자로 분사가 되거 나 섬유상으로 방출되며, 바늘의 모양을 조절하여 섬유, 튜브, 리본, 벨트 등과 같은 다양한 형상의 결과물을 얻 을 수 있다. 전기방사법으로 얻어지는 나노섬유의 직경은 수십 수백 $\mathrm{nm}$ 에 이르며 대체로 균일하고 재현성이 우수 하기 때문에 1990년대 후반부터 세라믹 나노섬유를 제조 하기 위한 방법에 응용되어 왔으며 연구 성과의 발표와 보고도 지수적으로 증가하고 있다. 특히 자성재료의 나노 구조체는 고감도 센서나 초고집적 데이터 저장체인 스푠 트로닉스 디바이스 분야에 연구 가능성이 충분히 있다고 보고된 바 있으며, ${ }^{4,5)}$ 최근에는 나노크기의 재료 입자를 분산시킨 용액에서 노즐이탈방식을 cone-jet mode로 채택 하여 전자 디바이스의 패턴을 구현하는 연구가 이루어지 고 있다.6)

이 연구에서는 스피넬 구조를 가지는 $\mathrm{Ni}-\mathrm{Zn}$ 계 페라이 트 나노섬유를 전기방사법으로 제조하고 조성벌로 자기 득성을 분석하였다. $\mathrm{Ni}-\mathrm{Zn}$ 계 페라이트는 최근 $\mathrm{EMI}$ 필터 및 생의학적 분리물질 등에 적용하기 위한 연구가 많이 이루어 지고 있으며, 전기방사법으로 제조한 페라이트 나 


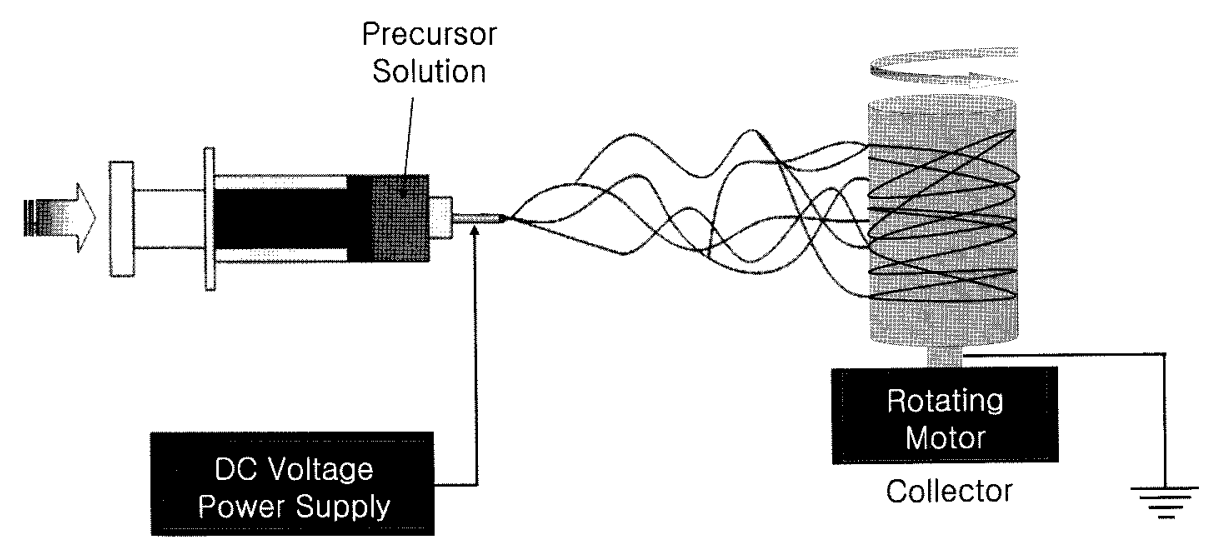

Fig. 1. Schematic diagram of experimental setup for electrospinning process.

노 섬유는 나노구조체로서 넓은 비표면적과 뛰어난 자성 특성을 갖고 있기 때문에 이와 같은 분야에 적용이 가능 할 것으로 판단된다. 용액의 점도와 열처리 온도가 나노 섬유의 형상과 미세구조에 어떠한 영향을 미치는지 조사 하였다.

\section{2. 실험 방법}

\section{1. 방사 용액 제조}

먼저 Iron (III) chloride( $\left.\mathrm{FeCl}_{3}\right)$ 를 N,N-Dimethylformamide $(\mathrm{DMF})$ 에 첨가하고 교반을 시켜서 용액 중에 완전하 녹 인다. 그 후, nickel (II) acetate tetrahydrate $\left(\left(\mathrm{CH}_{3} \mathrm{COO}\right)_{2} \mathrm{Ni}\right.$ $\left.\cdot 4 \mathrm{H}_{2} \mathrm{O}\right)$ 와 zinc acetate dihydrate $\left(\left(\mathrm{CH}_{3} \mathrm{COO}\right)_{2} \mathrm{Zn} \cdot 2 \mathrm{H}_{2} \mathrm{O}\right)$ 를 원하는 조성비로 칭량하여 용액에 첨가한 후, 완전히 섞 이도록 3시간 동안 교반시켰다. 준비된 용액에 점도를 부 여하기 위하여 Polyvinyl Pyrrolidone (PVP)을 사용하였다. PVP가 균질하게 녹아 들어가면 용액 내부의 잔류 기포를 제거하기 위해 밀폐된 용기에서 천천히 교반시키며 탈포 를 하였다.

\subsection{NiZn ferrite fiber 제조 및 특성 평가}

전기방사에 사용한 장비는 Fig. 1에 모식도로 나타내었 다. 준비된 용액을 $10 \mathrm{ml}$ 용량 주사기에 넣고 금속바늘을 노즐에 직접 연결한 후 방사를 한다. 이 때, 바늘과 콜렉 터 드럼 사이의 최단거리(Tip to Collector Distance, TCD) 는 $10 \mathrm{~cm}$ 간격으로 유지하고 $10 \mathrm{kV}$ 의 직류전압을 바늘에 직접 인가하였으며 토출량은 $2 \mathrm{~m} / / \mathrm{h}$ 로 일정하게 유지하였 다. 얻어진 섬유상의 금속염/폴리머 복합체는 $600^{\circ} \mathrm{C}$ 에서 3 시간 동안 하소를 하였으며, 이 때 승온과 하강속도는 $2^{\circ} \mathrm{C} / \mathrm{min}$ 으로 정밀하게 제어하였다. 하소 후에 $900 \sim 1200^{\circ} \mathrm{C}$ 까지 후속 열처리과정을 통해 나노섬유의 미세구조의 변 화과정을 관찰하였다.

전기방사를 위한 용액의 점도는 PVP함량에 따라 크게 변하므로 신뢰도가 높은 측정을 위하여 두 가지의 점도
측정 장비 $(500 \mathrm{cP}$ 이하 측정: LVDV-II+P CP, $500 \mathrm{cP}$ 이상 측정: RVDV-II+PRO/Brookfield)를 사용하였으며, 스핀들 (spindle)은 평판형(disk type)을 사용하였다. 각기 다른 점 도의 용액에서 스핀들의 정보와 장비의 차이를 배제하기 위해 shear rate에 따른 점도를 측정하였으며, 점도가 안 정화되는 $2.3 \mathrm{sec}^{-1}$ 의 shear rate를 기준점으로 하여 측정하 였다.

방사 후에 얻어진 열처리 전의 나노 섬유는 시차열중 량분석기(TG-DTA, Model TGASSDTA 851E/Mettler Toledo)를 통해 열적 특성을 관찰한 후 열처리 온도를 결 정하였다. 제조된 $\mathrm{NiZn}$ ferrite 나노섬유의 결정상은 X-선 회절분석기(XRD, X-ray diffractometer, 2311-B/Rigaku)를 이용하여 분석하였으며, 열처리 온도 별 섬유의 결합 형 태를 확인하기 위하여 적외선 분광분석(FT-IR, Fourier transform infrared, Vertex 80V/Bruker Optics)을 하였다.

$\mathrm{NiZn}$ ferrite 나노섬유의 미세구조는 전계 방출형 주사 전자현미경(FE-SEM, field emission scanning electron microscopy, JSM 6700F/Jeol)을 이용하여 관찰하였으며 투 과전자현미경(TEM, transmission electron microscopy, $\mathrm{JEM} 2100 / \mathrm{Jeol})$ 을 이용하여 회절패턴과 미세구조를 관찰 하였다. 자기특성은 진동형 시료 자기측정기(VSM, vibrating sample magnetometer, Model 7307/Lake Shore)를 사용하 여 상온에서 측정하였다.

\section{3. 결과 및 고찰}

금속염을 첨가하지 않고 $\mathrm{PVP}$ 의 양을 조절하였을 때의 점도 변화와 각각 다른 점도에서 전기방사를 하였을 때 얻어지는 섬유상의 형태는 Fig. 2에서 나타내었다. 균질 하게 제조된 용액은 속도 구배와 전단응력의 관계가 $\tau=$ $\mu(\mathrm{dv} / \mathrm{dh})$ 을 만족하는 뉴턴 유체의 거동을 보였다. 점도가 $200 \mathrm{cP}$ 이하에서는 섬유상과 동시에 비드(bead)상이 관찰 되었으며, 점도가 증가할수록 비드상의 개수가 감소하였 다. 비드상이 검출되는 점도 조건에서는 테일러콘이 불안 


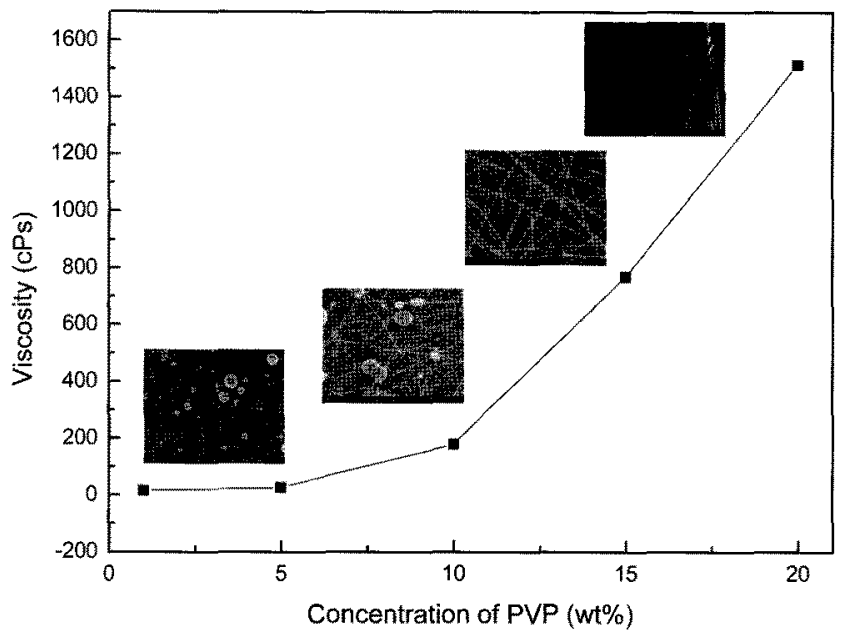

Fig. 2. SEM micrographs of fiber morphology with various viscosity of PVP/DMF solution at $2.3 \mathrm{sec}^{-1}$ shear rate.

정하게 진동하는 것을 관찰할 수 있었으며, 이는 강한 전 기장이 형성된 환경에 직접 노출된 액적(droplet)이 방사 용액이 갖고 있는 표면장력과 점도 둥의 여러 힘들의 균 형을 무너뜨리기 때문이다. 용액이 전기장 하에서 어느 정도 안정하여야만 균일한 섬유상을 생성할 수 있으며, 용액의 안정성은 점도와 비례함을 알 수 있었다. Fig. 2 에서 보는 바와 같이 섬유의 직경은 점도가 증가할수록 커지며, 이는 Huang 둥기이 용액의 점도가 높을수록 PVP 용액의 응집력이 매우 높아지게 되고, 그로 인해 강한 전 기장 내에서 용액이 비교적 안정하기 때문에 섬유의 직 경이 대체로 균일하고 굵어지게 된다고 보고한 바 있다. 하지만 점도가 지나치게 높아지게 되면 얻어지는 섬유의 직경이 크게 증가하게 된다. 따라서 용액에 적절한 점도 제어를 통한 용액의 안정성을 유지하는 것이 전기방사 공 정을 통한 나노섬유를 제조함에 있어서 가장 중요한 실 험변수라 할 수 있다.

이 연구에서 비드상이 나타나지 않는 용액의 PVP함량 은 $15 \mathrm{wt} \%$ 와 $20 \mathrm{wt} \%$ 이며, 점도는 각각 $770,1717 \mathrm{cP}$ 였다. 그리고 전자현미경 사진에서 판단한 섬유의 평균직경은 각각 $389.75 \mathrm{~nm}$ 와 $877.22 \mathrm{~nm}$ 였다. 따라서 전기방사법으로 $100 \mathrm{~nm}$ 내외의 직경을 가진 페라이트 나노섬유를 제조하 기 위해 용액의 점도를 $300 \sim 700 \mathrm{cP}$ 로 유지하였다. 제조 된 나노섬유는 시차 중랑열분석을 통해 열처리 온도를 결 정하였으며, 그 결과는 Fig. 3에 나타내었다. 열분석을 위 한 시편은 $\mathrm{Ni}_{0.4} \mathrm{Zn}_{0.6} \mathrm{Fe}_{2} \mathrm{O}_{4}$ 를 목표조성으로 하는 용액을 제 조한 다음, 방사 직후에 얻어진 web 형상의 나노섬유 그 대로 소량 떼어내어 준비하였고, $5^{\circ} \mathrm{C} / \mathrm{min}$ 의 승온율로 $900^{\circ} \mathrm{C}$ 까지 측정하였다. 열분석 곡선에서 $100^{\circ} \mathrm{C}$ 이하에서 홉열피크가 미약하게 나타나는 것은 섬유 내에서 잔류하 고 있던 $\mathrm{DMF}$ 와 방사 후에 흡수된 수분의 증발로 인한 것이며, 약 $6 \%$ 의 질량이 감소함을 알 수 있었다. 270

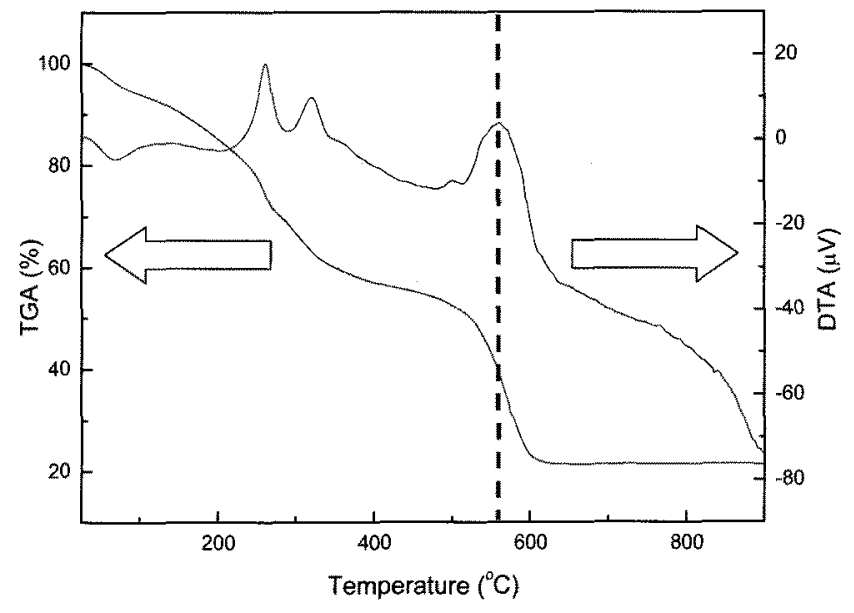

Fig. 3. TG-DTA curve of metal salts/PVP solution.

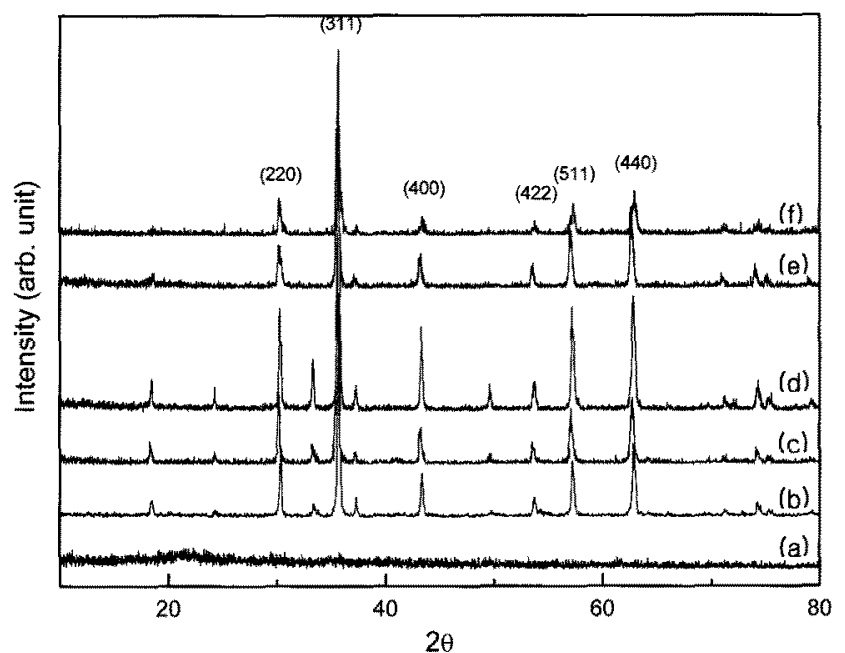

Fig. 4. $\mathrm{XRD}$ patterns of $\mathrm{Ni}_{0.4} \mathrm{Zn}_{0.6} \mathrm{Fe}_{2} \mathrm{O}_{4}$; (a) as-spun, (b) calcined at $600^{\circ} \mathrm{C}$, (c) fired at $900^{\circ} \mathrm{C}$ after $600^{\circ} \mathrm{C}$ calcination, (d) fired at $1000^{\circ} \mathrm{C}$ after $600^{\circ} \mathrm{C}$ calcination, (e) fired at $1100^{\circ} \mathrm{C}$ after $600^{\circ} \mathrm{C}$ calcination, (f) fired at $1200^{\circ} \mathrm{C}$ after $600^{\circ} \mathrm{C}$ calcination.

$320^{\circ} \mathrm{C}$ 에서 PVP 결합고리(chain)의 분해에 의한 발열피크 이며, $560^{\circ} \mathrm{C}$ 부근에 나타나는 발열피크는 금속염에 존재 하던 염소산기와 아세트산기의 분해에 의한 것으로 판단 된다. $600^{\circ} \mathrm{C}$ 이후부터는 중량 감소가 더 이상 일어나지 않기 때문에, 방사 후의 섬유는 열분석 결과를 바탕으로 $600^{\circ} \mathrm{C}$ 이상의 온도로 하소하였고, 열처리 온도를 변화시 키면서 나노섬유의 미세구조와 결정학적 특성을 평가하였다.

각 온도에 따른 결정상 분석은 Fig. 4에 나타내었다. X 선 회절 분석을 통해 $\mathrm{NiZn}$ 페라이트 섬유는 전형적인 스 피넬 구조를 하고 있음을 알 수 있었으며, $1100^{\circ} \mathrm{C}$ 이상의 온도에서는 회절켜크 크기가 감소하는 경향을 나타내었 다. 그리고 $33^{\circ}, 49^{\circ}$ 부근에서 나타나는 피크는 비화학양 론적 조성의 $\mathrm{NiZn}$ 페라이트에서 발생하는 $\mathrm{ZnO}$ 상에 해당 


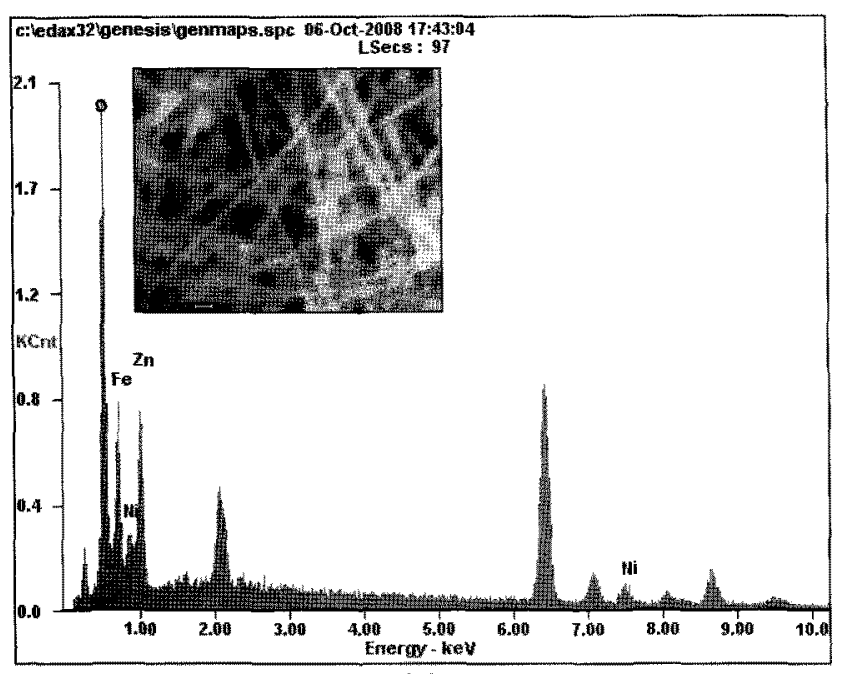

(a)

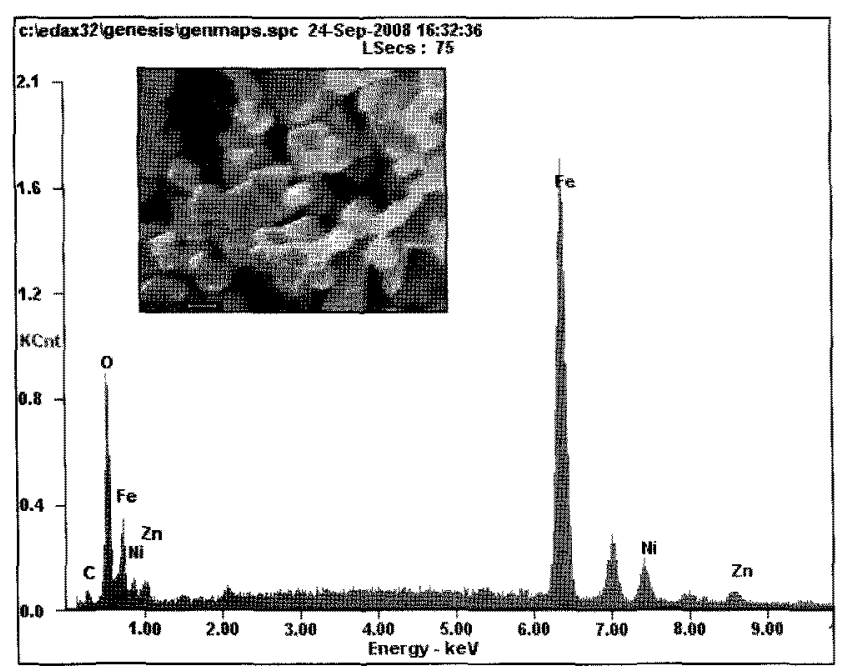

(b)

Fig. 5. EDS analysis of $\mathrm{Ni}_{0.4} \mathrm{Zn}_{0.6} \mathrm{Fe}_{2} \mathrm{O}_{4}$ fiber samples fired at different temperatures; (a) $600^{\circ} \mathrm{C}$, (b) $1200^{\circ} \mathrm{C}$.

하는 (002), (110)면인 것으로 각각 판단되며, 이는 $\mathrm{He}$ 둥 ${ }^{8)}$ 이 입증한 바 있다. $\mathrm{ZnO}$ 피크는 $1100^{\circ} \mathrm{C}$ 이상의 온도에 서는 나타나지 않았으며 회절피크의 감소와 더불어 판단 해볼 때, 고온으로 인해 $\mathrm{Zn}$ 가 휘발한다고 판단하였다.

Fig. 5 는 $600^{\circ} \mathrm{C}$ 에서 하소한 $\mathrm{Ni}_{0.4} \mathrm{Zn}_{0.6} \mathrm{Fe}_{2} \mathrm{O}_{4}$ 나노 섬유와 다시 $1200^{\circ} \mathrm{C}$ 에서 열처리하여 제조한 시편에 대한 $\mathrm{EDS}$ 분 석 결과이다. $2 \mathrm{keV}$ 부근에서 나타나는 피크는 $\mathrm{EDS}$ 에서 시편의 상을 찾기 위해 사용한 $\mathrm{Pt}$ 의 피크이며, 미약하게 나타나는 $\mathrm{CK}_{a}$ 피크는 PVP가 연소하였을 때 방생하는 잔 류 탄소와 시편을 고정하기 위한 카본 테잎의 영향이라 고 판단한다. 피크의 크기에서 볼 수 있듯이 $600^{\circ} \mathrm{C}$ 에서 하소를 한 시편의 경우 $\mathrm{Zn}$ 가 $\mathrm{Ni}$ 보다 훨씬 강한 것을 알 수 있으며, 이는 시편의 조성과 거의 일치하였다. 하지만 $1200^{\circ} \mathrm{C}$ 에서 열처리한 시편의 경우 $\mathrm{Zn}$ 가 눈에 띄게 감소

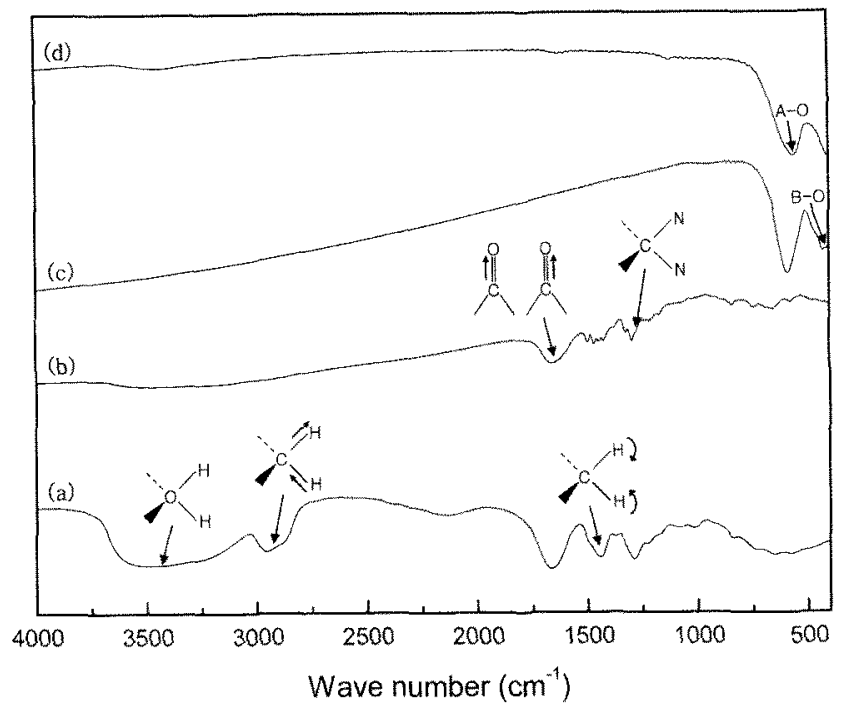

Fig. 6. IR spectra of fiber samples ; (a) pure PVP, (b) as-spun, (c) calcined at $600^{\circ} \mathrm{C}$, (d) fired at $1200^{\circ} \mathrm{C}$ after calcination at $600^{\circ} \mathrm{C}$

하는 것을 확인할 수 있었다. 이는 앞서 언급하였던 XRD 패턴에서 $\mathrm{Zn}$ 의 휘발을 뒷받침 할 수 있다.

Fig. 6에서는 방사용액을 제조함에 있어서 일어나는 반 응의 유무를 퐌단하고, PVP의 사슬 구조와 열처리 전후 공정에서 나노섬유의 결합상태를 분석하기 위해 IR 분광 분석 실험한 결과를 나타내었다. 각 파장에서의 결합과 진동양상은 Aldrich library of FT-IR spectra에서 조사를 하 였다. Fig. 6(a,b)에서의 $3450 \mathrm{~cm}^{-1}$ 파장에서 나타나는 피 크는 친수성이 강한 $\mathrm{PVP}$ 의 내부에 미량 잔류하고 있는 DMF와 수분의 O-H stretching vibration이며, $2930 \mathrm{~cm}^{-1}$, $1420 \mathrm{~cm}^{-1}$ 은 각각 $\mathrm{CH}_{2}$ 의 asymmetric vibration과 scissoring bending vibration이다. $1675 \mathrm{~cm}^{-1}$ 의 파장에서 나타나는 피크는 PVP의 amide carbonyl 그륩의 $\mathrm{C}=\mathrm{O}$ stretching vibration이며, $1290 \mathrm{~cm}^{-1}$ 에서는 C-N stretching vibration으 로 조사되었다. Fig. $6(\mathrm{a}, \mathrm{b})$ 의 IR 스펙트럼을 비교하였을 때, 첨가되어 있는 물질의 양에 따라 피크의 세기가 틀려 질 뿐이며, 특별한 변화는 관찰되지 않았다. 이런 결과를 바탕으로 PVP에 금속염이 첨가되었을 때 화학적 반응은 일어나지 않음을 알 수 있었다. Fig. $6(\mathrm{c})$ 는 $600^{\circ} \mathrm{C}$ 에서 열 처리하여 제조된 $\mathrm{NiZn}$ 페라이트 나노섬유이며, $580 \mathrm{~cm}^{-1}$, $400 \mathrm{~cm}^{-1}$ 는 각각 tetrahedral characteristic band와 octahedral characteristic band로 뚜렷이 구분되어젔다. Fig. 6(d)의 $1200^{\circ} \mathrm{C}$ 에서 열처리한 샘플에서는 스피넬구조의 tetrahedral site를 차지하고 있던 $\mathrm{Zn}$ vaporization으로 인하여 $580 \mathrm{~cm}^{-1}$ 의 푀크가 다소 감소하였다.

Fig. 7에서는 전기방사법을 이옹하여 제조한 metal salts/ PVP 섬유를 여러 온도로 열처리를 하였을 때의 형상을 나타내었다. $600^{\circ} \mathrm{C}$ 에서 얻어진 페라이트 나노섬유는 약 $10 \mathrm{~nm}$ 내외의 multiple grain들의 집합체로 이루어져 있으 


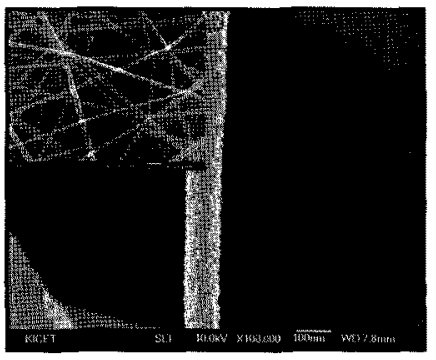

(a)

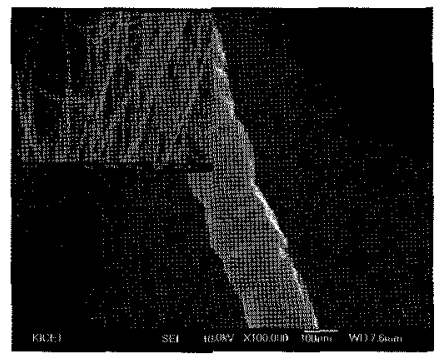

(b)

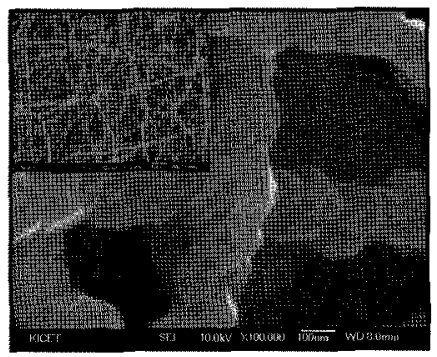

(c)

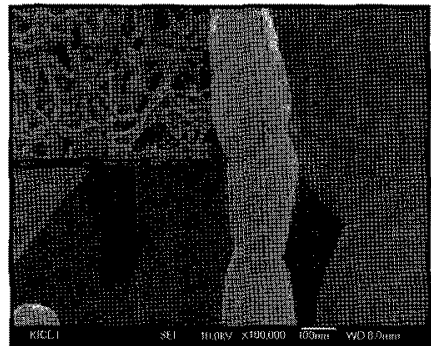

(d)

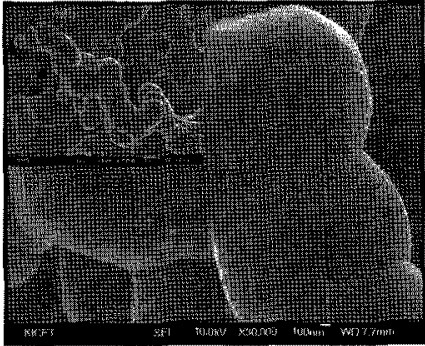

(e)

Fig. 7. $\mathrm{SEM}$ images of $\mathrm{Ni}_{0.4} \mathrm{Zn}_{0.6} \mathrm{Fe}_{2} \mathrm{O}_{4}$ fibers prepared at various firing conditions ; (a) calcined at $600^{\circ} \mathrm{C}$, (b) fired at $900^{\circ} \mathrm{C}$ after $600^{\circ} \mathrm{C}$ calcination, (c) fired at $1000^{\circ} \mathrm{C}$ after $600^{\circ} \mathrm{C}$ calcination, (d) fired at $1100^{\circ} \mathrm{C}$ after $600^{\circ} \mathrm{C}$ calcination, (e) fired at $1200^{\circ} \mathrm{C}$ after $600^{\circ} \mathrm{C}$ calcination.

며, 후속 열처리 과정을 거치면서 다면체형태의 입자성장 과 일정한 방항을 가진 facet을 관찰할 수 있었다. $900^{\circ} \mathrm{C}$ 에서는 주로 섬유를 구성하고 있는 미립자들이 인접한 위 치의 입자간에 결합으로 성장을 하는 반면에, $1000^{\circ} \mathrm{C}$ 의 열처리를 거친 섬유는 급격한 수축으로 인해 섬유간의 거 리가 가까워짐에 따라 섬유의 교차점에서 입자성장이 일 어나기 시작한다. 이러한 영향으로 나노 섬유는 굴곡이 심해지고 꼲어지기 시작하였다. $1200^{\circ} \mathrm{C}$ 의 열처리를 거친 샘플은 섬유형태라고는 할 수 없을 만큼 변형이 심하며, hill and valley structure가 뚜렷하게 관찰되었다. Fig, 8은 $600^{\circ} \mathrm{C}$ 에서 하소한 $\mathrm{Ni}_{0.4} \mathrm{Zn}_{0.6} \mathrm{Fe}_{2} \mathrm{O}_{4}$ 폐라이트 섬유의 투과

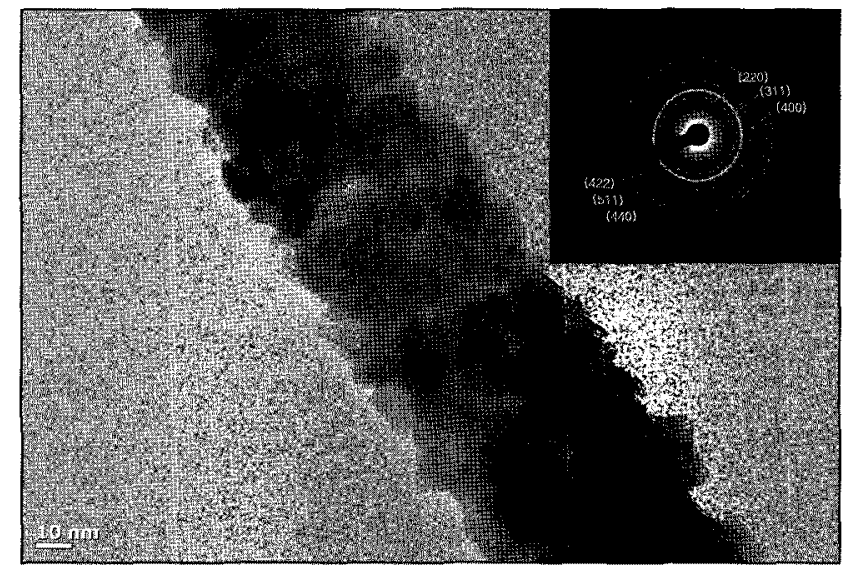

Fig. 8. TEM image and diffraction pattern of $\mathrm{Ni}_{0.4} \mathrm{Zn}_{0.6} \mathrm{Fe}_{2} \mathrm{O}_{4}$ nanofiber calcined at $600^{\circ} \mathrm{C}$.
전자 현미경 사진과 전자 회절 패턴을 나타내었다. 투과 전자현미경 사진에서 분석한 결과, $10 \mathrm{~nm}$ 의 평균입경을 가진 입자들의 집합임을 알 수 있었다. 그리고 X-선 회절 패턴과 원형 전자 회절 패턴으로 미루어 볼 때, 전기방사 법으로 제조된 $\mathrm{NiZn}$ 페라이트 나노섬유는 다결정 특성을 보임을 알 수 있었으며, 원형패턴들의 세기로 비교하였을 때, Fig. 4에서 나타낸 X-선 회절의 패턴과 동일하였다.

이러한 형상을 가진 $\mathrm{Ni}_{\mathrm{x}} \mathrm{Zn}_{1-\mathrm{x}} \mathrm{Fe}_{2} \mathrm{O}_{4}(\mathrm{x}=0.2,0.4,0.6,0.8$, 1.0 ) 나노섬유를 각각 $600^{\circ} \mathrm{C}$ 에서 하소하였을 때의 자기특 성은 Fig. 9에 나타내었다. Fig. 9(a)에 나타낸 바와 같이, $\mathrm{x}=0.4$ 의 조성에서 포화자화 $\left(\mathrm{M}_{\mathrm{s}}\right)$ 값이 가장 높게 얻어졌 으며, 이는 조성 별로 자기 모멘트를 계산하였을 떼 이론 적인 값과 유사하였다. $\mathrm{x}=0.2$ 일 때의 포화 자화 값의 계 산치는 $x=0.4$ 일 때보나 중가한 반면, 실측 치는 급격히 감소하게 되는데 이러한 오차에 대해서 Guillaud ${ }^{9}$ 는 4면 체자리에 $\mathrm{Fe}^{3+}$ 가 감소함으로써 초교환상호작용이 상대적 으로 약하게 되어 반평행성이 파괴되기 때문이라고 설명 하였다. 한편, Fig. 9(b)는 포화자화 값이 가장 높은 조성 인 $\mathrm{x}=0.4$ 의 페라이트 섬유를 각 온도별로 열처리를 하였 을 때 포화자화 $\left(\mathrm{M}_{\mathrm{s}}\right)$ 와 보자력 $\left(\mathrm{H}_{\mathrm{c}}\right)$ 의 변화를 보여주고 있 다. 일반적으로 보자력에 영향을 미치는 오인은 입자의 크기, 형태, 밀도, 결정구조상 결함 등이 있다. 보자력은 온도가 증가할수록 꾸준히 감소하는 경향을 보이는데, 이 는 열처리 온도가 증가할수록 입자가 성장을 하게 됨으 로써 비표면적과 기공률이 감소하기 때문이라고 판단한 다. 그리고 입자 성장에 따라 자구(magnetic domain)의 크 


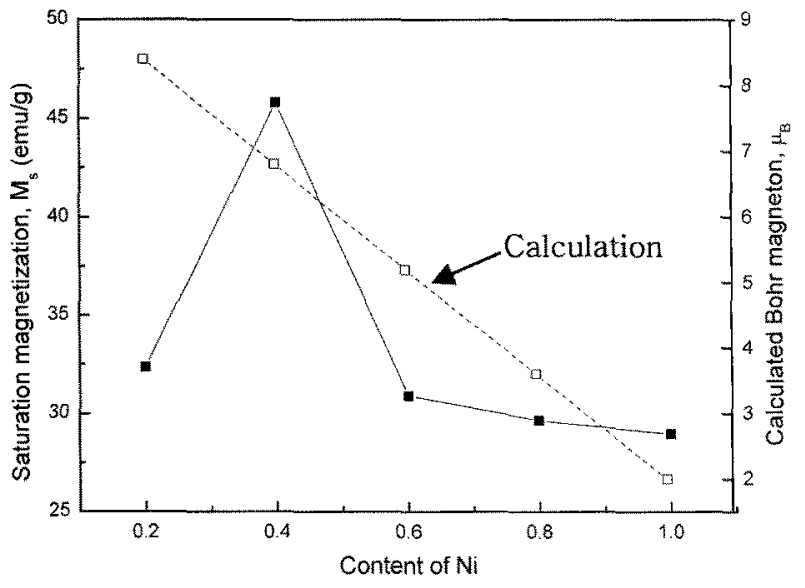

(a)

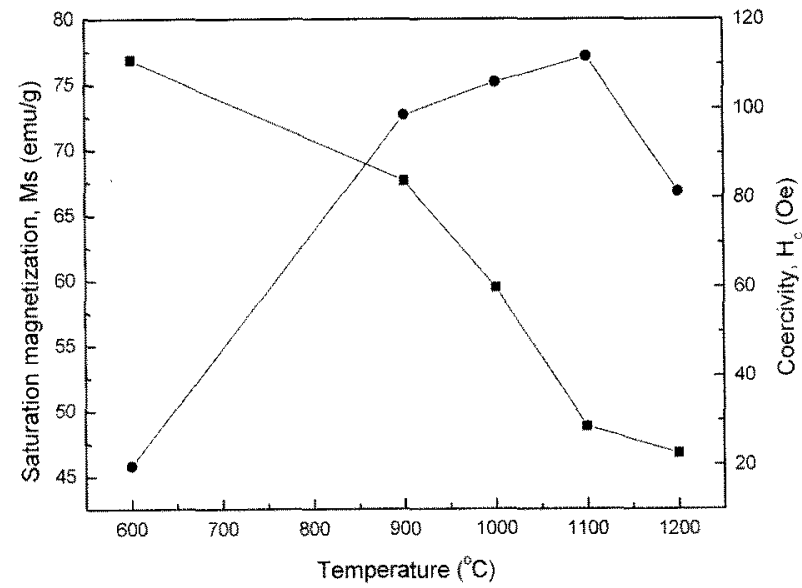

(b)

Fig. 9. Magnetic properties of NiZn ferrite fibers; (a) $M_{s}$ values of NiZn ferrite with Ni content. (b) $M_{s}($ $\mathrm{Ni}_{0.4} \mathrm{Zn}_{0.6} \mathrm{Fe}_{2} \mathrm{O}_{4}$ fiber.

기가 커지면서 자기모멘트의 버터합이 증가하기 때문에 포화자화는 열처리 온토가 증가할수록 값이 커지지만, $1200^{\circ} \mathrm{C}$ 로 열처리한 샘플을 경우 다시 포화자화값이 감소 하였다. 이러한 현상은 고온 열처리 과정 중에 발생하는 $\mathrm{Zn}$ vaporization으로 인한 국부적 $\mathrm{Zn}$ loss가 걸정네의 결 함 발생 원인으로 작용하기 때문인 것으로 판단한다.

일반적으로 inverse spinel ferrite 구조에서 $\mathrm{Zn}^{2+}$ 이온을 치환시키면 tetrahedral site를 점유하여 $\mathrm{Fe}^{3+}$ 이온을 octa hedral site로 이동시키는 역할을 하게 되어 자화량이 증 가하게 된다. ${ }^{10)}$ 또한, 열처리 온도가 증가함에 따라 grain size가 증가하여 포화자화값도 증가하게 되지만, $1100^{\circ} \mathrm{C}$ 이상에서는 $\mathrm{Zn}$ loss로 인해 NiZn ferrite에서 상대적인 $\mathrm{Zn}$ content가 감소하고 $\mathrm{Zn}^{2+}$ 의 자리에 $\mathrm{Ni}^{2+}$ 이온과 $\mathrm{Fe}^{3+}$ 이온의 확산이 일어나면서 오히려 포화자화는 감소하는 경향을 나타내는 것으로 추츠ㅇㅚㅚㄷㅏ. 한편, NiZn ferrite의 자기규칙 도가 $\mathrm{Zn}$ vaporization로 인해 영향을 받기 때문에 전체적 인 자기모멘트는 감소하는데, 이는 Fig. 5의 $\mathrm{EDS}$ 결과에 나타넨 바와 같이, $\mathrm{Zn}^{2+}$ 와 $\mathrm{O}^{2-}$ 이온에 대한 피이크가 현저 하게 감소한 이유와 입치하는 것으로 판단한다.

\section{4. 결 론}

이 연구에서는 다양한 금속염으로 부터 제조한 전구체 를 사용하여 전기방사법에 의해 사용하여 섬유상을 얻은 후, 열처리를 하여 NiZn 페라이트 $\left(\mathrm{Ni}_{x} \mathrm{Zn}_{1-\mathrm{x}} \mathrm{Fe}_{2} \mathrm{O}_{4}\right)$ 나노섬유 조건별로 제조한 특성 변화에 대해 연구한 결과 다음과 같은 결론을 얻을 수 있었다.

전기방사법으로 균일한 상태의 나노섬유를 언기 위해 서는 방사 용액의 점도 제어가 가장 중오하며, 이 연구에 서는 $300 \sim 700 \mathrm{cP}$ 의 범위에서 $100 \mathrm{~nm}$ 내외의 직경을 가진 as-spun 상태의 섬유를 제조하였으며, 하소과정을 거쳐서
$\mathrm{NiZn}$ 페라이트 나노섬유를 합성하였다. 스피넬구조의 단 일상을 언기 위한 하소온도는 $600^{\circ} \mathrm{C}$ 로서 이는 일반적인 고상합성법보다 약 $200^{\circ} \mathrm{C}$ 정도 낮은 온도이다. 따라서 이 연구에서의 폐라이트 나노섬유 형성 기구는 금속염(metal chloride, acetate)이 분헤되면서 핵이 생성되어 성장하는 열분해 공정(pyrolysis process)에 해당하는 것으로 판단되 다. $600^{\circ} \mathrm{C}$ 이상의 온도로 열처리를 하였을 때 multiple grains은 성장을 하게 되며, $900^{\circ} \mathrm{C}$ 의 온도까지는 인접한 입자들 간의 결합이 일어나지만, $1000^{\circ} \mathrm{C}$ 부터는 섬유의 수 축으로 인해 섬유가 서로 교차된 위치에서 접합이 발생 하게 된다. $1200^{\circ} \mathrm{C}$ 이상에서 열처리한 경우에는 입자의 크기가 매우 커지게 되므로 사실상 섬유 형상이 붕괴된 것으로 퐌단된다. 열처리 온도가 높아감에 따라 증가하였 던 포화자화값은 $1200^{\circ} \mathrm{C}$ 부터 감소한 이유는 $\mathrm{Zn}$ 의 휘발 로 인해 결정 내에 결함이 발생하였기 때문인 것으로 판 단된다.

방사 후의 열처리 제어를 통해 multiple grains의 크기를 더욱 작게 만들고, 내부 기공을 형성시켜서 비표면적을 넓게 만들 경우, 나노 섬유 형태의 $\mathrm{NiZn}$ 페라이트 소제 는 다강체(multiferroics), 센서, 필터, 촉매나 생의학적 분 리 또는 약물 전달 물질 등 많은 분야에 적용이 가능할 겻으로 기대된다.

\section{Acknowledgment}

이 연구는 2008년도 지식경제부 소재월천기술개발사업 의 연구비 지원으로 수행되었습니다.

\section{REFERENCES}

1. Y. Xia, P. Yang, Y. Sun, Y. Wu, B. Mayer, B. Gates, Y. Yin, 
F. Kim, and H. Yan, "One-Dimensional Nanostructures : Synthesis, Characterization, and Applications," Adv. Mater. 15 353-89 (2003).

2. Dan Li and Younan Xia, "Electrospinning of Nanofibers: Reinventing the Wheel?," Adv. Mater., 16 [14] 1151-70 (2004).

3. R. P. A. Hartman, D. J. Brunner, D. M. A. Camelot, J. C. M. Marijnissen, and B. Scarlett, "Electrohydrodynamic Atomization in the Cone-jet Mode Physical Modeling of the Liquid Cone and Jet," J. Aerosol Sci, 30 [7] 823-49 (1999).

4. D. A. Allwood, Gang Xiong, M. D. Cooke, C. C. Faulkner, D. Atkinson, N. Vernier, and R. P. Cowburn, "Submicrometer Ferromagnetic NOT gate and Shift Register," Science, 296 2003-06 (2002).

5. S. A. Wolf, D. D. Awschalom, R. A. Buhrman, J. M. Daughton, S. Von Molnar, M. L. Roukes, A. Y. Chtchelkanova, and D. M. Treger, "Spintronics: A Spin-Based Electronics Vision for the Future," Science, 294 1488-95
(2001).

6. J. H. Yu, S. Y. Kim, and J. Hwang, "Effect of Viscosity of Silver Nanoparticle Suspension on Conductive Line Patterned by Electrohydrodynamic Jet Printing," Appl. Phys. A, 89 157-59 (2007).

7. Z. M. Huang, Y. Z. Zhang, M. Kotaki, and S. Ramakrishna, "A Review on Polymer Nanofibers by Electrospinning and Their Applications in Nanocomposites," Composites Science and Technology, 63 2223-53 (2003).

8. Xinhua He, Guosheng Song, and Jianhong Zhu, "Non-stoichiometric NiZn Ferrite by Sol-gel Processing," Mater. Lett., 59 1941-44 (2005).

9. C. Guillaud, "The Properties of Manganese-zinc Ferrites and the Physical Processes Governing Them," Proc. IEEE, 5 165-78 (1957).

10. S. Chikazumi, "Physics of Ferromagnetism( $2^{\text {nd }}$ ed.)," pp. 197-221, Oxford University Press Inc., chapter 9, 1997. 